Data Report

\title{
Plausible Role of Environmental Factors on COVID-19 Transmission in the Megacity Delhi, India
}

\author{
Saginela Ravindra Babu ${ }^{\text {* }}$, N. Narasimha $\mathrm{Rao}^{2}$, S. Vijaya Kumar ${ }^{3}$, Surender Paul $^{4}$, \\ Shantanu Kumar Pani ${ }^{5 *}$ \\ ${ }^{1}$ Center for Space and Remote Sensing Research, National Central University, Taoyuan 32001, Taiwan \\ ${ }^{2}$ Department of Geophysics, Banaras Hindu University, Varanasi 221005, India \\ ${ }^{3}$ Department of Information Technology, Rajeev Gandhi Memorial College of Engineering and Technology, Nandyal \\ 518501, India \\ ${ }^{4}$ Meteorological Centre, India Meteorological Department, Chandigarh 160037, India \\ ${ }^{5}$ Department of Atmospheric Sciences, National Central University, Taoyuan 32001, Taiwan
}

\begin{abstract}
The role of environmental factors in the transmission of COVID-19 still needs to be determined. The main objective of the present study is to explore the relationship between environmental factors (both meteorological and air pollution parameters) and the daily confirmed COVID-19 cases over Delhi, India. This study employed a secondary data analysis of COVID-19 (from 1 March to 30 June, 2020) from the Delhi State Health Bulletin and the environmental factors from the Indian Meteorological Department (IMD) and Central Pollution Control Board (CPCB) of India. Pearson's correlation coefficients were assessed to show the correlation between environmental factors and daily confirmed COVID-19 cases. The temperature (maximum, minimum, average, and dew point) and wind speed exhibited a significant positive correlation with daily COVID-19 cases. However, diurnal temperature range, rainfall, and relative humidity showed non-significant correlations. Air pollutants were found to be weakly associated with daily COVID-19 cases. However, $\mathrm{O}_{3}$ exhibited a significant positive correlation with daily COVID-19 cases in Delhi. The probability distribution analysis reveals that approximately $80 \%$ of the total confirmed cases were registered when the average temperature was higher than $30^{\circ} \mathrm{C}$. The present study finds a prominent relationship between different environmental factors and COVID-19 transmission in Delhi. However, further detailed analysis over different parts of entire India is required to get a complete picture and solid conclusion.
\end{abstract}

Keywords: COVID-19; Temperature; Humidity; AQI; Delhi.

\section{INTRODUCTION}

The world is presently going through a very distressing stage with the spread of Coronavirus disease 2019 (COVID-19). This is highly contagious and has been declared by the World Health Organization (WHO) as a pandemic after the reporting of 118319 confirmed cases and 4292 deaths worldwide (WHO, 2020a). Since the start of COVID-19, large worldwide efforts have been constantly dedicated to improving the understanding about the virus. Recently, COVID-19 aerosol drivers, impacts, and mitigation studies have received immense global attentions (e.g., Hadei et al., 2020; Hsiao et al., 2020;

\footnotetext{
* Corresponding authors.

E-mail addresses: shantanukumarpani@gmail.com (S.K.

Pani); baburavindra595@gmail.com (S.R. Babu)
}

Jain and Sharma, 2020; Lednicky et al., 2020; Mohd Nadzir et al., 2020; Mutuku et al., 2020; Safarian et al., 2020; Suhaimi et al., 2020). Several studies confirmed that COVID-19 is generally transported, propagated, and transmitted by humans through respiratory droplets and close contacts (Chan et al., 2020; Hsiao et al., 2020; Lai et al., 2020; Li et al., 2020; Wang et al., 2020; WHO, 2020b). The survival and transmission of viruses by droplets are usually expedited in dry and cold weather conditions (Casanova et al., 2010). Moreover, the transmission of viruses can be affected by population density and the medical care quality (Casanova et al., 2010; Dalziel et al., 2018). Several studies claimed that weather conditions could influence the growth, viability, range of spread, and transmission of COVID-19 causing viruses (Hastie and Tibshirani, 1990; Chan et al., 2011; Van Doremalen et al., 2013; Chen et al., 2020). Recent studies have demonstrated significant correlations between meteorological parameters (i.e., temperature, humidity, wind speed) and the 
spread of COVID-19 pandemic (e.g., Bashir et al., 2020; Chen et al., 2020; Ma et al., 2020; Pani et al., 2020a; Sahin, 2020; Sajadi et al., 2020; Tosepu et al., 2020; Zhu et al., 2020). A positive correlation between mean temperature and COVID19 cases was reported in China (Zhu et al., 2020). A study by Tosepu et al. (2020) found a significant association between average temperature and COVID-19 pandemic in Indonesia. Wang et al. (2020) investigated the impact of temperature on the spread of COVID-19 and suggested that the temperature significantly affects the spread of COVID-19. However, other studies have stated contradictory results that weather conditions may not be associated with COVID-19 pandemic (e.g., Shi et al., 2020; Jamil et al., 2020). For example, Shi et al. (2020) reported a negative correlation between temperature and COVID-19 transmission based on daily weather reports. However, the exact information about the impact of weather conditions on the COVID-19 pandemic is still limited (specifically in tropical countries) and controversial.

Similarly, the knowledge about the impact of atmospheric pollution levels on the COVID-19 pandemic is still limited. Generally, better air quality enhances the quality of life and mainly relieves those who are suffering from respiratory problems. Exposure to air pollutants like carbon monoxide (CO), nitrogen oxides $\left(\mathrm{NO}_{\mathrm{x}}\right)$, ozone $\left(\mathrm{O}_{3}\right)$, particulate matters including finer $\mathrm{PM}_{2.5}$ (particulate matter $\leq 2.5 \mu \mathrm{m}$ in aerodynamic diameter) and coarser $\mathrm{PM}_{10}$ (particulate matter $\leq 10 \mu \mathrm{m}$ in aerodynamic diameter), polycyclic aromatic hydrocarbons (PAHs), and volatile organic compounds (VOCs) normally can induce several harmful health impacts including respiratory diseases in humans (Kelly and Fussell, 2011; Carugno et al., 2016; Pani et al., 2019a, b, 2020b; Sopian et al., 2020; Zoran et al., 2020). Moreover, exposure to air pollution induces oxidative stress, damages the immune system, and also lowers the host's ability and resistance to viral infections (Yin and Wunderink, 2018; Martelletti and Martelletti, 2020; Suhaimi et al., 2020). Hence, people with certain medical issues would probably face challenges to fight against the COVID-19 (Suhaimi et al., 2020).

India, the second most populated country in the world (with a population of 1.38 billion as of March, 2020; Ministry of Statistics and Programme Implementation, 2020), reported the first case of COVID-19 on 30 January, 2020. India currently has the largest number of confirmed cases in Asia with the number of total confirmed cases breaking the 100,000 and 200,000 marks on 19 May and 3 June, 2020, respectively. However, the fatality rate in India is relatively low $(2.8 \%)$ as compared to the global value $(6.13 \%)$ as of 3 June, 2020 (https://en.wikipedia.org/wiki/COVID-19_pand emic_in_India). Delhi, India is considered as one of the most polluted megacities in the world based on the environmental performance index (WHO, 2016). Moreover, Delhi is the second most populated city in the world (World Population Review, 2020). Although many factors have been shown to influence the COVID-19 incidence rate, this study primarily aims to investigate the role of Indian tropical weather in the transmission and spread of COVID-19 by exploring the correlations between environmental factors (both meteorological parameters and air pollutants) and COVID19 cases in the megacity Delhi, India. This kind of information is essential to show whether tropical climates, along with poor air quality are less or more favorable to the spread of the virus.

\section{MEASUREMENTS, DATA, AND METHODOLOGY}

\section{Study Area}

The present study domain includes the megacity Delhi in India. It is the second leading megacity in the world (The World's Cities in 2018, Data Booklet, United Nations, 2018) with 16.8 million of inhabitants and about the population density of 11297 persons per sq. km (https://www.niti.gov. $\mathrm{in} / \mathrm{niti} /$ content/population-density-sq-km). Delhi normally experiences four major distinct seasons, i.e., winter (December-February), summer (Mar-May), monsoon (JuneSeptember), and post-monsoon (October-November). Delhi experiences a semi-arid climate with an extremely hot summer, average rainfall, and a very cold winter (Kumar and Goyal, 2011). In general over Delhi, the temperature changes between $42^{\circ} \mathrm{C}$ and $48^{\circ} \mathrm{C}$ during summer and $4^{\circ} \mathrm{C}$ and $10^{\circ} \mathrm{C}$ in winter (Mahato et al., 2020). It was well reported that about $80 \%$ of the total annual precipitation over Delhi occurs during the monsoon (Perrino et al., 2011). Over Delhi, the weather during the winter period was significantly influenced by the western disturbances. Dust from the Sahara, Arabian deserts, Gulf, and the Thar Desert, mainly influence in premonsoon and post-monsoon seasons (Singh and Naseema, 2013; Tiwari et al., 2014).

\section{Datasets}

The data of daily confirmed COVID-19 cases and related deaths over Delhi were collected from the Delhi State Health Bulletin reports (http://health.delhigovt.nic.in). The daily data of basic meteorological parameters such as maximum temperature (MAX_T), minimum temperature (MIN_T), average temperature (Ave_T), diurnal temperature range (DTR), dew point, relative humidity (RH), wind speed (WS), and rainfall, from 1 March to 30 June, 2020 for the station New Delhi (Palam), was obtained from the India Meteorological Department (IMD; www.imd.gov.in). Simultaneous, daily concentrations of air pollutants such as $\mathrm{PM}_{2.5}, \mathrm{PM}_{10}, \mathrm{CO}, \mathrm{O}_{3}$, and $\mathrm{NO}_{\mathrm{x}}$ were obtained over the same station from the Central Pollution Control Board (CPCB) of Indian online portal for air quality data dissemination (https://app.cpcbccr. com/ccr/\#/caaqm-dashboard-all/caaqm-landing).

The air quality index (AQI) was computed in order to understand the overall improvement in air quality in Delhi. Details of AQI can be found elsewhere (CPCB, 2014; Sahu and Kota, 2017), and only a brief about it compiled here. AQI needs $\mathrm{PM}_{2.5}, \mathrm{PM}_{10}, \mathrm{CO}, \mathrm{SO}_{2}, \mathrm{NO}_{2}, \mathrm{O}_{3}, \mathrm{NH}_{3}$, and lead $(\mathrm{Pb})$; out of these minimum concentrations of at least three air pollutants must be available including either $\mathrm{PM}_{2.5}$ or $\mathrm{PM}_{10}$ (Sharma et al., 2020). The sub-index AQI for each pollutant can be estimated as follows (e.g., Sharma et al., 2020),

$$
A Q I_{i}=\frac{\left(I N_{H I}-I N_{L O}\right)}{\left(B_{H I}-B_{L O}\right)} \times\left(C_{i}-B_{L O}\right)+I N_{L O}
$$


where, $C_{i}$ represents the concentration of pollutant "i". $I N_{L O}$ and $I N_{H I}$ are the corresponding AQI values. $B_{L O}$ and $B_{H I}$ are the breakpoint concentrations smaller and greater to $C_{i}$. The overall AQI is the maximum $A Q I_{i}$ and corresponding air pollutant is the dominating one. AQI generally follows a scale of 0-500. AQI between 0-50, 51-100, 101-200, 201300, 301-400, and 401-500 represents good, satisfactory, moderate, poor, very poor, and severe, respectively.

In this study, we used the Pearson's correlation method to obtain the relationship between environmental factors (both meteorological parameters and air pollutants) and the confirmed daily COVID-19 cases. The Pearson's correlation method measures the linear correlation between two variables. It has a value between +1 and -1 , where 1 is a total positive linear correlation, 0 is no linear correlation, and -1 is a total negative linear correlation. This method is widely used in scientific analyses.

\section{RESULTS AND DISCUSSION}

\section{Temporal Evolution of the COVID-19 Cases}

Fig. 1 presents the temporal pattern of the daily total confirmed COVID-19 cases and the related mortality over Delhi during the study period (1 March-30 June, 2020). Over Delhi, the first confirmed COVID-19 case was reported on 2 March, 2020 and first death due to the COVID-19 was reported on 14 March, 2020. As of 16 July, 2020, the reported total confirmed COVID-19 cases and the related deaths were 116993 and 3487, respectively (http://health.delhigovt.nic.in). However, after 30 March, the confirmed daily COVID-19
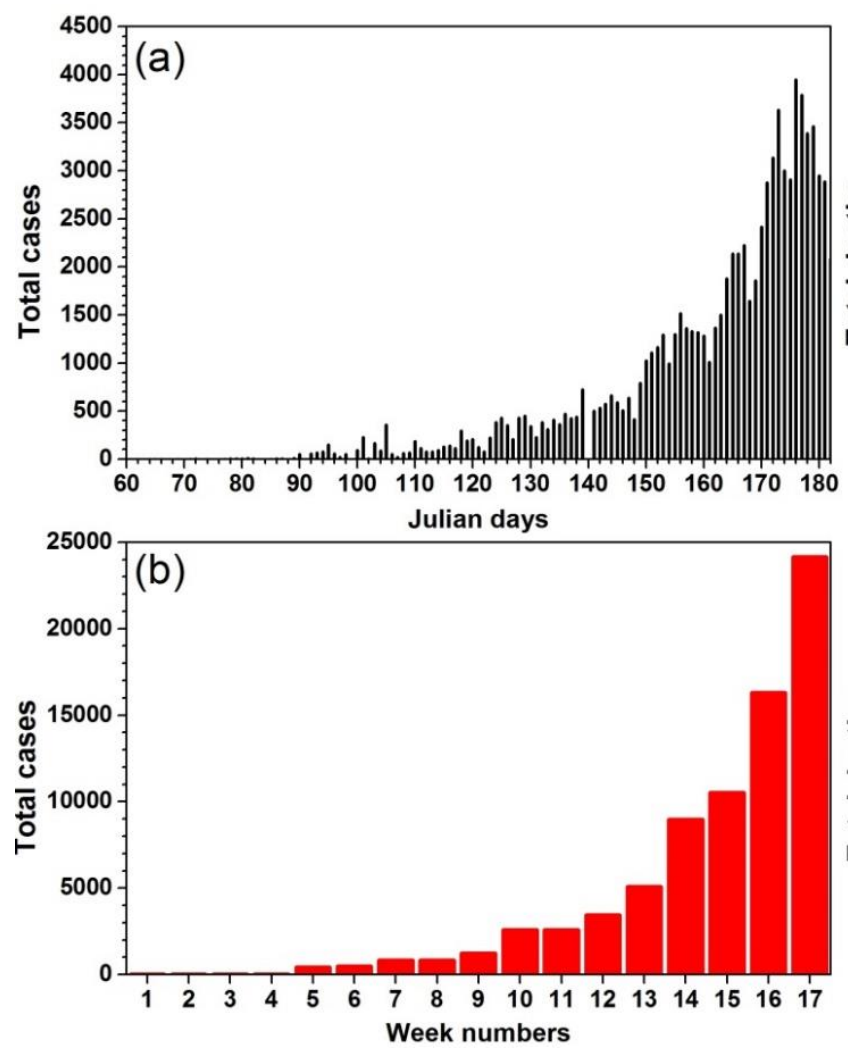

cases were sharply increased in Delhi. Surprisingly, a total of 437 deaths was reported on 17 June, 2020 (https://www. hindustantimes.com/india-news/why-was-there-a-sudden-s pike-in-coronavirus-deaths-in-delhi/story-HsIUJ8CutTRPjM $869 \mathrm{oz}$ 1VL.html); however, the data for this particular day is removed from the database as an outlier while doing the correlation analyses. Furthermore, we distributed the daily confirmed COVID-19 cases and deaths with respect to each week during the entire study period (Figs. 1(b) and 1(d)). We considered 1-7 March, 2020 as a first week and so on up to 30 June, 2020. A total of $\sim 17$ weeks of data for the entire study period was included in this study. The observed COVID-19 confirmed cases (deaths) for each week (1-11) are as follows, $4(0), 5(1), 18(0), 12(0), 406(5), 458(8)$, 804 (28), 807 (11), 1224 (8), 2580 (7), 2577 (55), 3424 (85), 5067 (190), 8948 (310), 10490 (506), 16292 (821), and 24124 (457). COVID-19 cases sharply increased after the $5^{\text {th }}$ week and reached the peak in the $17^{\text {th }}$ week. In the case of mortality, we noticed two significant peaks during the $15^{\text {th }}$ and $16^{\text {th }}$ weeks, respectively.

The day to day variations in different meteorological parameters over Delhi are shown in Fig. 2. The temperature shows significant variations during the study period (Fig. 2(a)). MAX_T was found as high as $47.6^{\circ} \mathrm{C}$ on $27 \mathrm{May}, 2020$. The observed mean Ave_T was $28.8 \pm 5.4^{\circ} \mathrm{C}$ during the entire study period. Similarly, the dew point over Delhi shows a significant day to day variations varying from $10.7^{\circ} \mathrm{C}$ to $26.8^{\circ} \mathrm{C}$ with the mean value of $18.9 \pm 3.9^{\circ} \mathrm{C}$. Interestingly, a gradual increase in the dew point is evident particularly during the month of June, 2020 (Fig. 2(b)). As well-known

Fig. 1. Daily and weekly COVID-19 cases along with associated deaths from March 1 to June 30, 2020 in Delhi, India. 

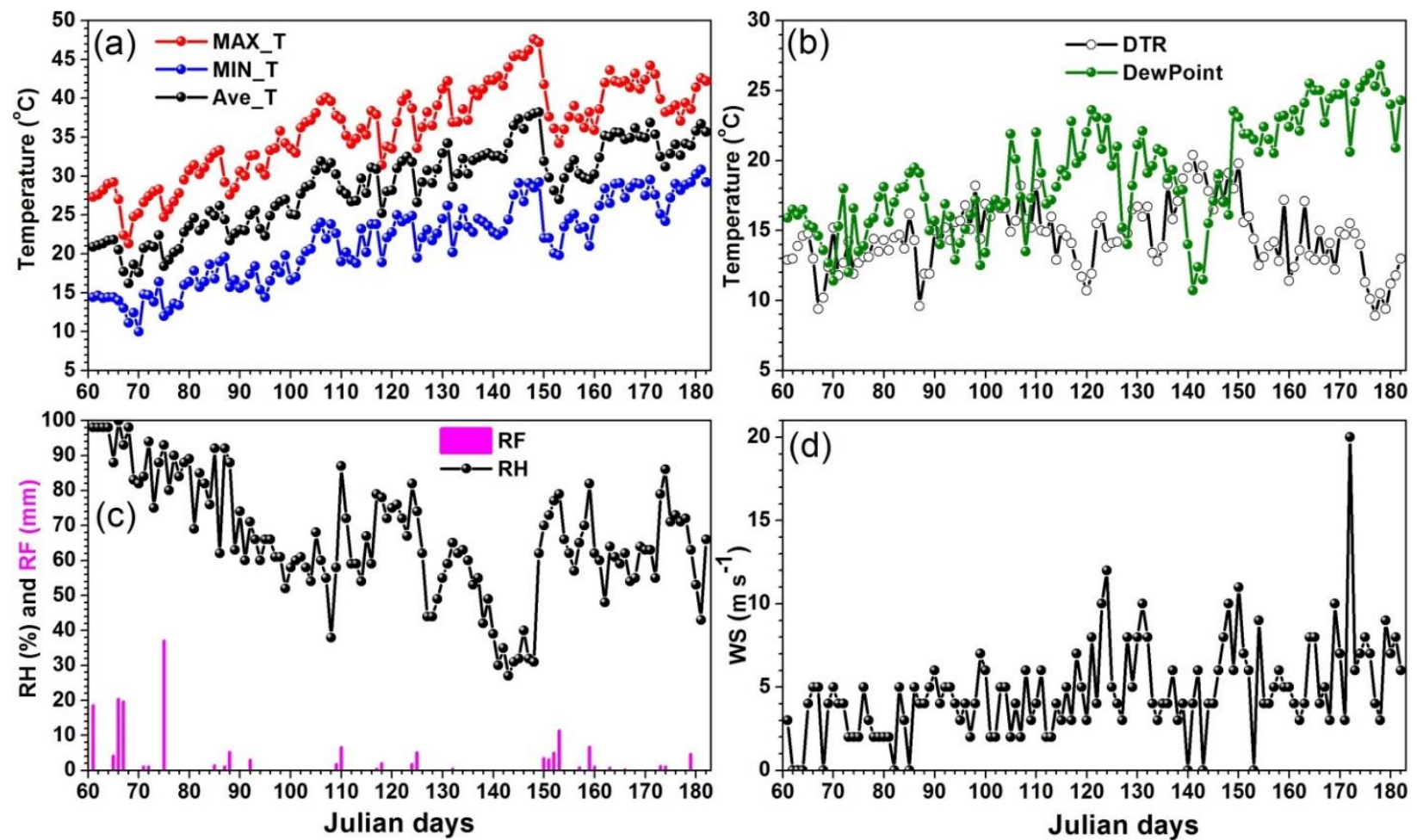

Fig. 2. Day-to-day variations in meteorological parameters over Delhi during March 1-June 30, 2020.

that the dew point is the temperature to which air must be cooled to become saturated without changing the pressure and this is greatly associated with the human comfort. It was also reported that high values of dew point $\left(>23^{\circ} \mathrm{C}\right)$ would be uncomfortable for humans and can induce heat stress (e.g., Pani et al., 2020a). The RH also shows a large daily variations (Fig. 2(c); range: $27-100 \%$ ) with a mean value of $66.5 \pm 16.7 \%$. The minimum RH during the study period was noticed in May, 2020. WS have also exhibited a large variability, ranging from 0 to $20 \mathrm{~m} \mathrm{~s}^{-1}$ with the mean value of $4.7 \pm 2.9 \mathrm{~m} \mathrm{~s}^{-1}$ (Fig. 2(d)). In the study period, highest rainfall about $37 \mathrm{~mm}$ was recorded over Delhi (Fig. 2(c)).

Similarly, the daily variations in air-pollution related parameters are shown in Fig. 3. The observed mean values for the different air pollutants during the study period are as follows, $\mathrm{CO}=0.8 \pm 0.5 \mathrm{mg} \mathrm{m}^{-3}, \mathrm{O}_{3}=26 \pm 10 \mu \mathrm{g} \mathrm{m}^{-3}, \mathrm{NO}_{\mathrm{x}}=$ $37 \pm 39 \mathrm{ppbv}, \mathrm{PM}_{10}=113 \pm 50 \mu \mathrm{g} \mathrm{m}^{-3}, \mathrm{PM}_{2.5}=44 \pm 17 \mu \mathrm{g} \mathrm{m}^{-3}$, and $A Q I=107 \pm 44$. The Indian government had implemented four phases (24 March-14 April 14; 15 April-3 May; 4-7 May, and 18-31 May in 2020) of lockdown (total or partial) in India to control the spread of COVID-19 (https://www.m ygov.in/corona-data/covid19-statewise-status). All the air pollutants (except $\mathrm{O}_{3}$ ) exhibited a sharp decrease in their concentrations due to the reductions of anthropogenic activities including traffic movements and industrial operations owing to the enforcement of national lockdown in India. AQI over Delhi was mostly moderate (within 100-200 for 57 days) during the study period.

\section{Correlation between Environmental Factors and COVID-19 Cases}

Fig. 4 shows the results of correlation analysis between the number of confirmed COVID-19 cases and different environmental factors (both meteorological parameters and air pollutants) in Delhi. Significant positive correlations of temperature (MAX_T, MIN_T, and Ave_T) and dew point with confirmed daily COVID-19 cases were evident (Fig. 4) in Delhi. Interestingly, Min_T and dew point temperature exhibited better correlations with COVID-19 cases as compared to Max_T, Ave_T, and DTR. Similarly, temperature (MAX_T, MIN_T, and Ave_T) and dew point also showed significant positive correlations with mortality (deaths). However, RH exhibited a weak negative correlation ( $\mathrm{r}=$ -0.16) with COVID-19 cases over Delhi. A significant positive correlation $(r=0.46)$ was evident between WS and COVID-19 cases. DTR and rainfall were not significantly correlated with COVID-19 daily cases. Deaths showed a significant positive correlation $(\mathrm{r}=0.6)$ with Ave_T, but a negative correlation $(r=-0.19)$ with $\mathrm{RH}$. From the results based on correlation analysis, it can be concluded that the daily Ave_T, MIN_T, dew point and WS were strongly associated with the daily confirmed COVID-19 cases in Delhi, India. In the case of air pollution parameters, only $\mathrm{O}_{3}$ exhibited a significant positive correlation with COVID-19 cases while others showed weak negative correlations.

Overall, the observed correlations of daily COVID-19 cases with Ave_T and RH in Delhi were well-matched with the previous reports of Bashir et al. (2020), Tosepu et al. (2020) and Ma et al. (2020). Bashir et al. (2020) also reported the positive correlation of COVID-19 cases with temperature and negative association with humidity in New York, USA. A significant association $(r=0.39)$ of COVID-19 with average temperature was observed in Jakarta, Indonesia (Tosepu et al., 2020). Ma et al. (2020) reported a negative 

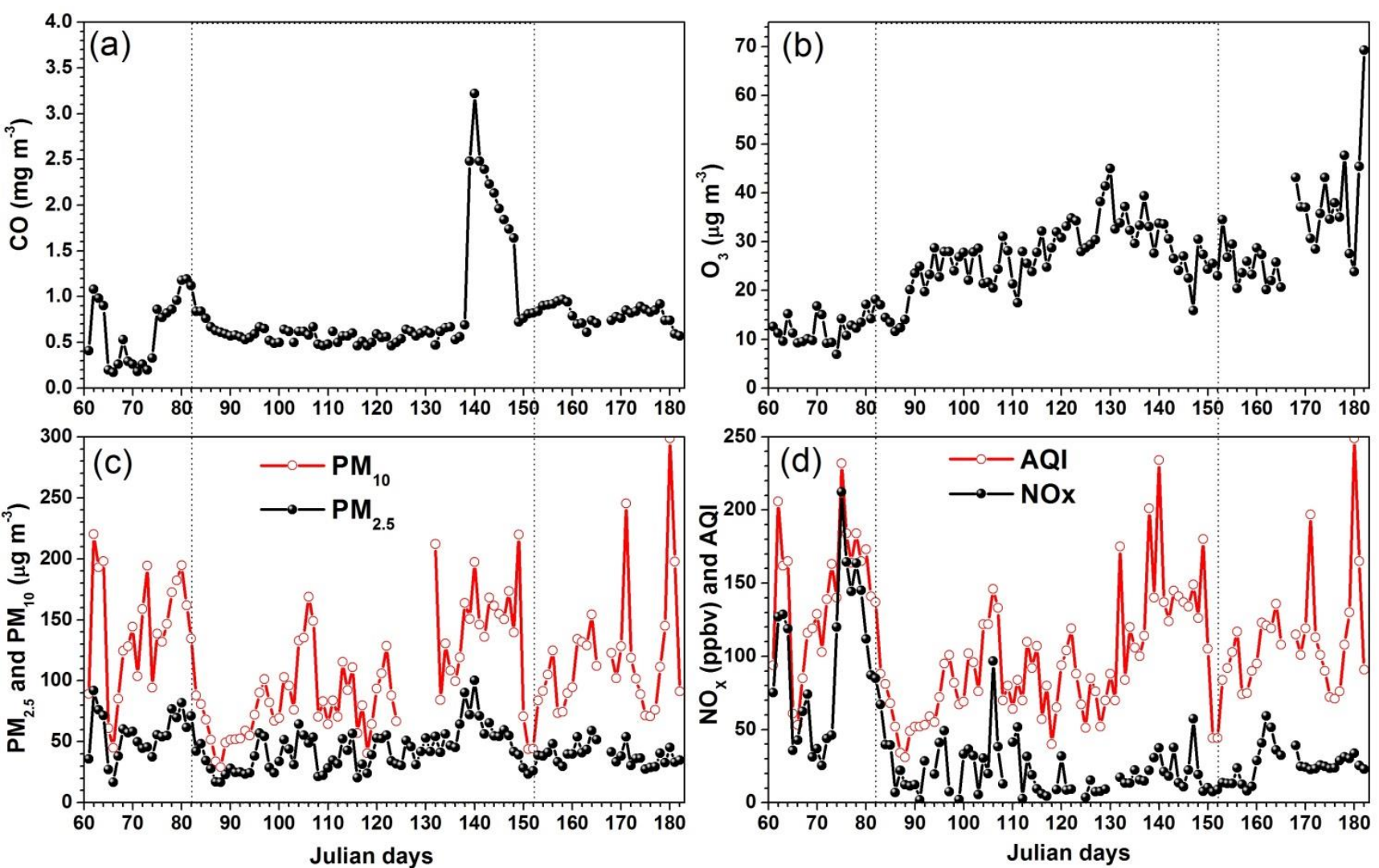

Fig. 3. Day-to-day variations in different air pollution parameters over Delhi during March 1-June 30, 2020. The dotted vertical box represents the lockdown period implemented by the Indian government in India.

correlation of COVID-19 daily death counts with RH ( $\mathrm{r}=$ -0.32 ), in Wuhan, China. However, we noticed a higher correlation $(r=0.6)$ between Ave_T and COVID-19 daily cases in Delhi, India as compared to the study over Jakarta, Indonesia.

\section{The Probability Distribution of COVID-19 Cases}

The total COVID-19 cases were further distributed with respect to different thresholds of Ave_T and RH. During the entire study period, the observed minimum Ave_T was $16.2^{\circ} \mathrm{C}$ and the maximum Ave_T was $38.2^{\circ} \mathrm{C}$ in Delhi. Likely, the minimum $\mathrm{RH}$ was $27 \%$ and the maximum $\mathrm{RH}$ was $100 \%$. We made nine and eight thresholds for the distribution of total COVID-19 cases based on Ave_T and $\mathrm{RH}$, respectively. Thresholds for Ave_T were $<20^{\circ} \mathrm{C}, 20$ $22^{\circ} \mathrm{C}, 22-24^{\circ} \mathrm{C} 24-26^{\circ} \mathrm{C}, 26-28^{\circ} \mathrm{C}, 28-30^{\circ} \mathrm{C}, 30-32^{\circ} \mathrm{C}, 32-$ $34^{\circ} \mathrm{C}$ and $>34^{\circ} \mathrm{C}$. Similarly, thresholds for the RH were $<30 \%, 30-40 \%, 40-50 \%, 50-60 \%, 60-70 \%, 70-80 \%, 80$ $90 \%$ and $>90 \%$. The observed total COVID-19 cases and deaths for each Ave_T and RH thresholds are shown in Fig. 5 and the detailed statistics are presented in Table 1.

Results showed that $50.3 \%$ of the COVID-19 cases and $60.2 \%$ of deaths were associated with the Ave_T higher than $34^{\circ} \mathrm{C}$. It was also noticed that $23.4 \%$ of the COVID- 19 cases and $16.9 \%$ of deaths were associated with the Ave_T ranges between $32^{\circ} \mathrm{C}$ and $34^{\circ} \mathrm{C}$ (Fig. 5). Interestingly, only one and ten COVID-19 cases (zero deaths) were noticed when the Ave_T was $<20^{\circ} \mathrm{C}$ and between $20^{\circ} \mathrm{C}$ and $22^{\circ} \mathrm{C}$, respectively.
The observed mean RH for these two Ave_T thresholds was $88.2 \pm 7.4 \%$ and $91.25 \pm 7.7 \%$. Similarly, out of a total of 122 days, 24 days were associated with Ave_T higher than $34^{\circ} \mathrm{C}$ and 35 days were associated with Ave_T ranges between $30^{\circ} \mathrm{C}$ and $34^{\circ} \mathrm{C}$.

Similar statistics were seen with respect to RH. About $33.8 \%$ of COVID-19 cases and $45.4 \%$ of deaths were found when the RH was between $60 \%$ and $70 \%$. Out of a total of 122 days of data period, 21 days were associated with the same criteria $(60-70 \%$ of $\mathrm{RH})$. During this period, the mean Ave_T was observed as $30.4 \pm 4.3^{\circ} \mathrm{C}$. Overall, $\sim 66 \%$ of COVID-19 cases and $\sim 76 \%$ of deaths were associated with RH between $27 \%$ and $70 \%$. These results showed that high RH and normal Ave_T $\left(\sim 20-25^{\circ} \mathrm{C}\right)$ were strongly associated with lower numbers of daily COVID-19 cases in Delhi.

\section{CONCLUSIONS}

In the present study, we investigated the plausible relationship between environmental factors (both meteorological parameters and air pollutants from 1 March to 30 June, 2020) and the COVID-19 daily cases in the megacity Delhi, India. For this study, we utilized meteorological parameters from the India Meteorological Department and air pollution parameters from the Central Pollution Control Board (CPCB). COVID-19 showed a statistically significant positive correlation with temperature, whereas a weak negative correlation with $\mathrm{RH}$. This finding 


\section{(a)}

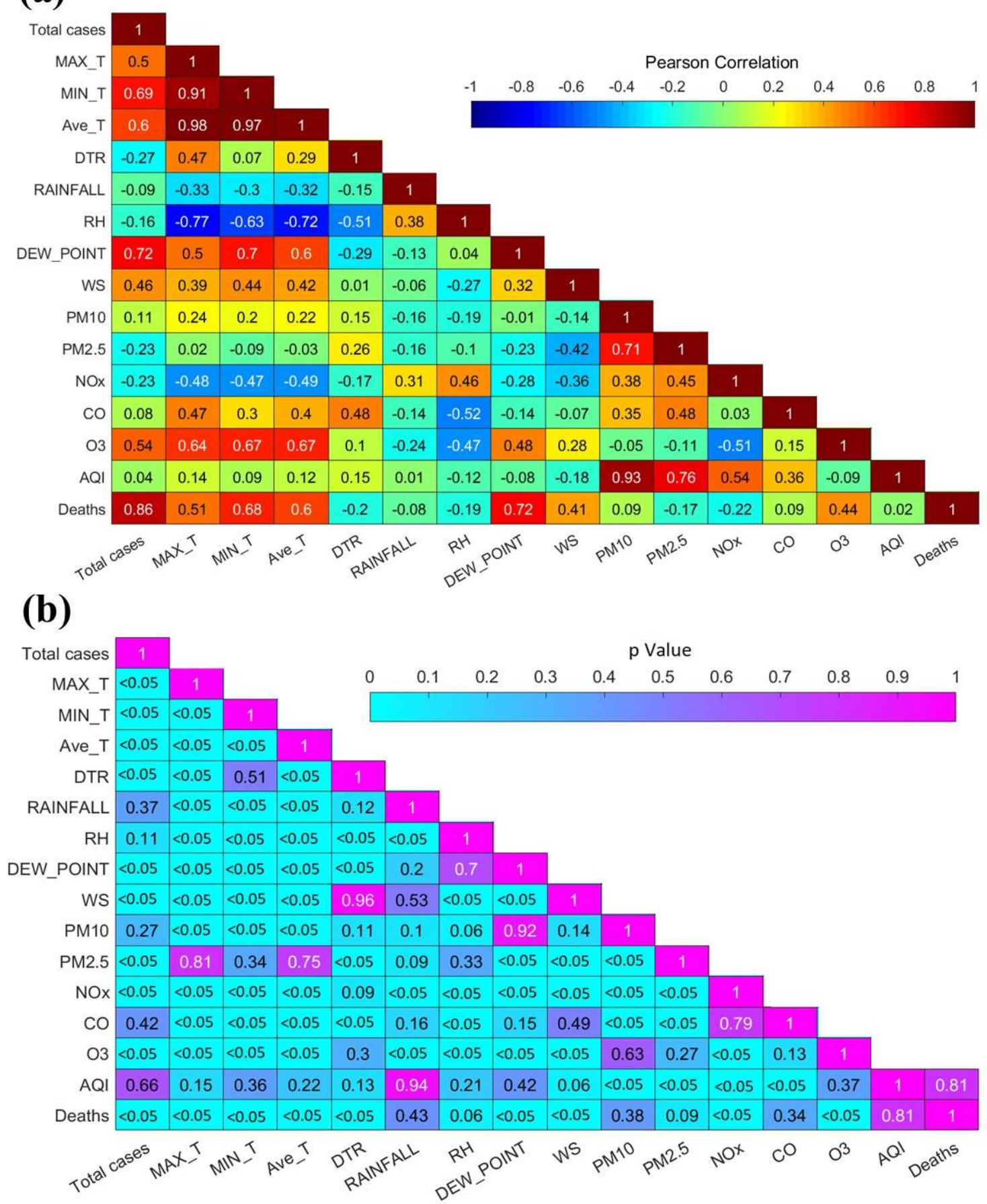

Fig. 4. Heat map of (a) Pearson correlation coefficient matrix and (b) respective $p$ values for different environmental factors with total COVID-19 cases and associated deaths.

over Delhi was found corroborated with recently reported data over other locations (e.g., Bashir et al., 2020; Ma et al., 2020; Tosepu et al., 2020). Dew point temperature was found to be closely related to the number of daily COVID19 cases and the related mortality. It was observed that the WS exhibited a significant positive correlation with daily COVID-19 cases over Delhi, indicating that the virus might be able to transmigrate with high wind. We also observed a prominent positive correlation of $\mathrm{O}_{3}$ with daily COVID-19 cases in Delhi. The observed probability analysis revealed that the count of daily confirmed COVID-19 cases was significantly associated with a certain range of weather conditions. For example, the results showed that a higher number of COVID-19 cases were associated with the combination of RH between 50-80\% and the higher Ave_T $\left(>30^{\circ} \mathrm{C}\right)$. However, only nine confirmed COVID-19 cases and zero deaths were evident when the weather was associated with high RH (> 90\%) and low Ave_T $\left(\sim 20^{\circ} \mathrm{C}\right)$ conditions. 

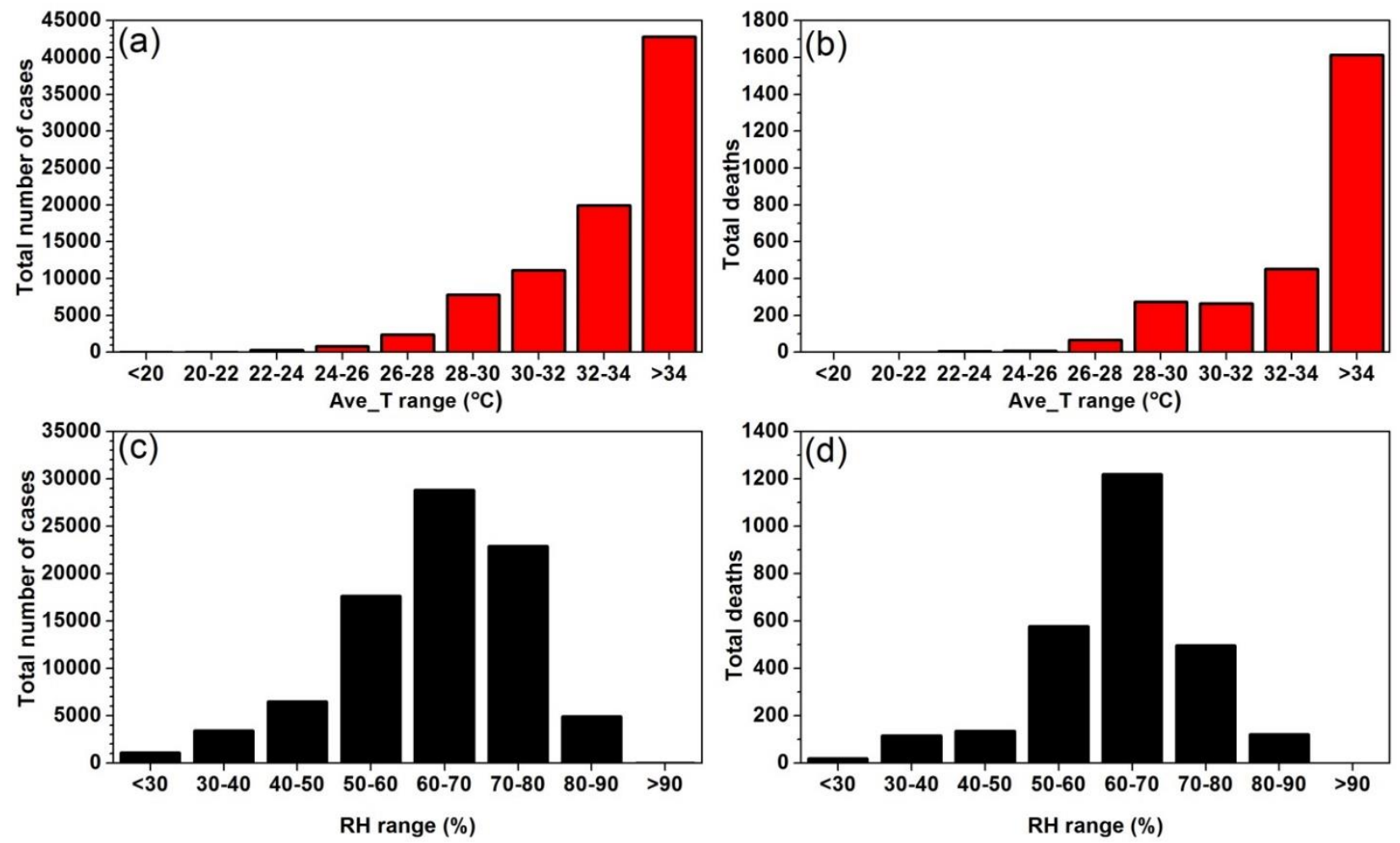

Fig. 5. Probability distribution of (a) COVID-19 daily cases and (b) mortality in different thresholds of Ave_T. Subplot (c) and (d) are same as (a) and (b) but for RH.

Table 1. COVID-19 total confirmed cases and deaths in different thresholds with respect to Ave_T $\left({ }^{\circ} \mathrm{C}\right), \mathrm{RH}(\%)$, and AQI.

\begin{tabular}{cllll}
\hline Ave_T range & Total cases & Total deaths & Corresponding RH & Total days \\
\hline$<20$ & $1(0.001 \%)$ & 0 & $88.2( \pm 7.4)$ & 6 \\
$20-22$ & $10(0.01 \%)$ & 0 & $91.2( \pm 7.7)$ & 12 \\
$22-24$ & $295(0.35 \%)$ & $4(0.15 \%)$ & $75.5( \pm 12.2)$ & 10 \\
$24-26$ & $807(0.95 \%)$ & $7(0.3 \%)$ & $72.8( \pm 11.9)$ & 10 \\
$26-28$ & $2386(2.8 \%)$ & $66(2.5 \%)$ & $64.9( \pm 7.8)$ & 12 \\
$28-30$ & $7801(9.2 \%)$ & $274(10.2 \%)$ & $66.7( \pm 12.3)$ & 13 \\
$30-32$ & $11145(13.1 \%)$ & $264(9.8 \%)$ & $63.0( \pm 12.3)$ & 15 \\
$32-34$ & $19892(23.4 \%)$ & $452(16.9 \%)$ & $55.7( \pm 14.3)$ & 24 \\
$>34$ & $42824(50.3 \%)$ & $1613(60.2 \%)$ & $52.9( \pm 13.9)$ & Total days \\
RH range & Total cases & Total deaths & Corresponding Ave_T & 2 \\
$<30$ & $1071(1.26 \%)$ & $18(0.7 \%)$ & $33.4( \pm 1.13)$ & 7 \\
$30-40$ & $3402(3.9 \%)$ & $116(4.3 \%)$ & $35.3( \pm 2.6)$ & 26 \\
$40-50$ & $6496(7.6 \%)$ & $135(5.04 \%)$ & $32.6( \pm 2.6)$ & 31 \\
$50-60$ & $17599(20.6 \%)$ & $576(21.5 \%)$ & $30.5( \pm 3.9)$ & 21 \\
$60-70$ & $28809(33.8 \%)$ & $1218(45.4 \%)$ & $30.4( \pm 4.3)$ & 16 \\
$70-80$ & $22868(26.8 \%)$ & $496(18.5 \%)$ & $28.3( \pm 4.2)$ & 11 \\
$80-90$ & $4907(5.8 \%)$ & $121(4.5 \%)$ & $23.6( \pm 4.3)$ & 8 \\
$>90$ & $9(0.01 \%)$ & 0 & $20.7( \pm 2.6)$ & Total days \\
AQI range & Total cases & Total deaths & ---- & 58 \\
$<100$ & $31706(39.2 \%)$ & $780(30.4 \%)$ & ---- & 57 \\
$101-200$ & $45710(56.6 \%)$ & $1707(66.5 \%)$ & ---- & 5 \\
$201-300$ & $3387(4.2 \%)$ & $80(3.1 \%)$ & -- & \\
\hline
\end{tabular}

Similarly, the relatively less number of COVID-19 cases $(12 \%)$ and deaths $(10 \%)$ were associated with minimum $\mathrm{RH}$ $(<50 \%)$. Overall, the present analysis shows that there was a clear relationship between COVID-19 cases and environmental factors such as temperature, $\mathrm{RH}, \mathrm{WS}$, and $\mathrm{O}_{3}$. However, this study also includes several limitations since the meteorological and air pollutant data were taken from one single station which may affect correlations. However, this preliminary 
study provides needful information for the general public to understand the environmental factors influencing on COVID-19 transmission over Delhi. A more detailed analysis over different parts of the country is required to conclude the plausible role of the environmental factors in the spread of COVID-19 in India.

\section{FUNDING}

This research did not receive any specific grant from funding agencies in the public, commercial, or not-for-profit sectors.

\section{DECLARATION OF COMPETING INTEREST}

The authors declare that they have no known competing financial interests or personal relationships that could have appeared to influence the work reported in this paper.

\section{ACKNOWLEDGMENT}

The authors acknowledge the India Meteorological Department and Central Pollution Control Board, New Delhi for the necessary meteorology and air pollution datasets used in this study.

\section{REFERENCES}

Bashir, M.F., Ma, B., Bilal, Komal, B., Bashir, M.A., Tan, D. and Bashir, M. (2020). Correlation between climate indicators and COVID-19 pandemic in New York, USA. Sci. Total Environ. 28: 138835. https://doi.org/10.1016/j. scitotenv.2020.138835

Carugno, M., Consonni, D., Randi, G., Catelan, D., Grisotto, L., Bertazzi, P.A., Biggeri, A. and Baccini, M. (2016). Air pollution exposure, cause-specific deaths and hospitalizations in a highly polluted Italian region. Environ. Res. 147: 415-424. https://doi.org/10.1016/j.env res.2016.03.003

Casanova, L.M., Jeon, S., Rutala, W.A., Weber, D.J. and Sobsey, M.D. (2010). Effects of air temperature and relative humidity on coronavirus survival on surfaces. Appl. Environ. Microbiol. 76: 2712-2717. https://doi.org/ 10.1128/AEM.02291-09

Chan, J.F.W., Yuan, S., Kok, K.H., To, K.K.W., Chu, H., Yang, J., Xing, F., Liu, J., Yip, C.C.Y., poon, R.W.S., Tsoi, H.W., Lo, S.K.F., Chan, K.H., Poon, V.K.M., Chan, W.M., Daniel, J., Cai, J.P., Cheng, V.C.C., Chen, H., Hui, C.K.M. and Yuen, K.Y. (2020). A familial cluster of pneumonia associated with the 2019 novel coronavirus indicating person-to-person transmission: A study of a family cluster. Lancet 395: 514-523. https://doi.org/10.10 16/S0140-6736(20)30154-9

Chan, K.H., Peiris, J.S., Lam, S.Y., Poon, L.L.M., Yuen, K.Y. and Seto, W.H. (2011). The effects of temperature and relative humidity on the viability of the SARS coronavirus. Adv. Virol. 2011: 734690. https://doi.org/10. 1155/2011/734690

Chen, B., Liang, H., Yuan, X., Hu, Y., Xu, M., Zhao, Y.,
Zhang, B., Tian, F. and Zhu, X. (2020). Roles of meteorological conditions in COVID-19 transmission on a worldwide scale. medRxiv 2020.03.16.20037168. https://doi.org/10.1101/2020.03.16.20037168

Dalziel, B.D., Kissler, S., Gog, J.R., Viboud, C., Bjørnstad, O.N., Metcalf, C.J.E. and Grenfell, T. (2018). Urbanization and humidity shape the intensity of influenza epidemics in U.S. cities. Science 362: 75-79. https://doi.org/10.1126/science.aat6030

Hadei, M., Hopke, P.K., Jonidi, A. and Shahsavani, A. (2020). A letter about the airborne transmission of SARS-CoV-2 based on the current evidence. Aerosol Air Qual. Res. 20: 911-914. https://doi.org/10.4209/aaqr.2020.04.0158

Hastie, T.J. and Tibshirani, R.J. (1990). Generalized additive models. Chapman., Hall, New York.

Hsiao, T.C., Chuang, H.C., Griffith, S.M., Chen, S.J. and Young, L.H. (2020). COVID-19: An aerosol's point of view from expiration to transmission to viral-mechanism. Aerosol Air Qual. Res. 20: 905-910. https://doi.org/10.4 209/aaqr.2020.04.0154

Jain, S. and Sharma, T. (2020). Social and travel lockdown impact considering coronavirus disease (COVID-19) on air quality in megacities of India: Present benefits, future challenges and way forward. Aerosol Air Qual. Res. 20: 1222-1236. https://doi.org/10.4209/aaqr.2020.04.0171

Jamil, T., Alam, I. S., Gojobori, T. and Duarte, C. (2020). No evidence for temperature-dependence of the COVID19 epidemic. Front. Public Health 8: 436. https://doi.org/ 10.3389/fpubh.2020.00436

Kelly, F.J. and Fussell, J.C. (2011). Air pollution and airway disease. Clin. Exp. Allergy 41: 1059-1071. https://doi.org/ 10.1111/j.1365-2222.2011.03776.x

Kumar, A. and Goyal, P. (2011). Forecasting of air quality in Delhi using principal component regression technique. Atmos. Pollut. Res. 2: 436-444. https://doi.org/10.5094/ APR.2011.050

Lai, C.C., Shih, T.P., Ko, W.C., Tang, H.J. and Hsueh, P.R. (2020). Severe acute respiratory syndrome coronavirus 2 (SARS-CoV-2) and coronavirus disease-2019 (COVID-19): The epidemic and the challenges. Int. J. Antimicrob. Agents 55: 105924. https://doi.org/10.1016/j.ijantimicag. 2020.105924

Lednicky, J.A., Shankar, S.N., Elbadry, M.A., Gibson, J.C., Alam, M.M., Stephenson, C.J., Eiguren-Fernandez, A., Morris, J.G., Mavian, C.N., Salemi, M., Clugston, J.R. and Wu, C.Y. (2020). Collection of SARS-CoV-2 virus from the air of a clinic within a university student health care center and analyses of the viral genomic sequence. Aerosol Air Qual. Res. 20: 1167-1171. https://doi.org/10. 4209/aaqr.2020.02.0202

Li, Q., Guan, X., Wu, P., Wang, X., Zhou, L., Tong, Y., Ren, R., leung, K.S.M., Lau, E.H.Y., Wong, J.Y., Xing, X., Xiang, N., Wu, Y., Li, C., Chen, Q., Li, D., Liu, T., Zhao, J., Liu, M., ... and Feng, Z. (2020). Early transmission dynamics in Wuhan, China, of novel coronavirusinfected pneumonia. N. Engl. J. Med. 382: 1199-1207. https://doi.org/10.1056/NEJMoa2001316

Ma, Y., Zhao, Y., Liu, J., He, X., Wang, B., Fu, S. and Luo, B. (2020). Effects of temperature variation and humidity 
on the death of COVID-19 in Wuhan, China. Sci. Total Environ. 724: 138226. https://doi.org/10.1016/j.scitotenv. 2020.138226

Mahato, S., Pal, S. and Ghosh, K.G. (2020). Effect of lockdown amid COVID-19 pandemic on air quality of the megacity Delhi, India. Sci. Total Environ. 730: 139086. https://doi.org/10.1016/j.scitotenv.2020.139086

Martelletti, L. and Martelletti, P. (2020). Air pollution and the novel Covid-19 disease: A putative disease risk factor. SN Compr. Clin. Med. 15: 1-5. https://doi.org/10.1007/s 42399-020-00274-4

Ministry of Statistics and Programme Implementation (2020). Population of India. https://statisticstimes.com/de mographics/population-of-india.php

Mohd Nadzir, M.S., Ooi, M.C.G., Alhasa, K.M., Bakar, M.A.A., Mohtar, A.A.A., Nor, M.F.F.M., Latif, M.T., Hamid, H.H.A., Ali, S.H.M., Ariff, N.M., Anuar, J., Ahamad, F., Azhari, A., Hanif, N.M., Subhi, M.A., Othman, M. and Nor, M.Z.M. (2020). The impact of Movement Control Order (MCO) during pandemic COVID-19 on local air quality in an urban area of Klang Valley, Malaysia. Aerosol Air Qual. Res. 20: 1237-1248. https://doi.org/10.4209/aaqr.2020.04.0163

Mutuku, J.K., Hou, W.C. and Chen, W.H. (2020). An overview of experiments and numerical simulations on airflow and aerosols deposition in human airways and the role of bioaerosol motion in COVID-19 transmission. Aerosol Air Qual. Res. 20: 1172-1196. https://doi.org/10. 4209/aaqr.2020.04.0185

Pani, S.K., Ou-Yang, C.F., Wang, S.H., Ogren, J.A., Sheridan, P.J., Sheu, G.R. and Lin, N.H. (2019a). Relationship between long-range transported atmospheric black carbon and carbon monoxide at a high-altitude background station in East Asia. Atmos. Environ. 210: 86-99. https://doi.org/10.1016/j.atmosenv.2019.04.053

Pani, S.K., Chantara, S., Khamkaew, C., Lee, C.T. and Lin, N.H. (2019b). Biomass burning in the northern peninsular Southeast Asia: Aerosol chemical profile and potential exposure. Atmos. Res. 224: 180-195. https://doi.org/10.1 016/j.atmosres.2019.03.031

Pani, S.K., Lin, N.H. and RavindraBabu, S. (2020a). Association of COVID-19 pandemic with meteorological parameters over Singapore. Sci. Total Environ. 740: 140112. https://doi.org/10.1016/j.scitotenv.2020.140112

Pani, S.K., Wang, S.H., Lin, N.H., Chantara, S., Lee, C.T. and Thepnuan, D. (2020b). Black carbon over an urban atmosphere in northern peninsular Southeast Asia: Characteristics, source apportionment, and associated health risks. Environ. Pollut. 259: 113871. https://doi.org/ 10.1016/j.envpol.2019.113871

Perrino, C., Tiwari, S., Catrambone, M., Dalla Torre, S., Rantica, E. and Canepari, S. (2011). Chemical characterization of atmospheric PM in Delhi, India, during different periods of the year including Diwali festival. Atmos. Pollut. Res. 2: 418-427. https://doi.org/10.5094/A PR.2011.048

Safarian, S., Unnthorsson, R. and Richter, C. (2020). Effect of coronavirus disease 2019 on $\mathrm{CO}_{2}$ emission in the world. Aerosol Air Qual. Res. 20: 1197-1203. https://doi.org/10.4209/aaqr.2020.0.0151

Sahin, M. (2020). Impact of weather on COVID-19 pandemic in Turkey. Sci. Total Environ. 728: 138810. https://doi.org/10.1016/j.scitotenv.2020.138810

Sajadi, M.M., Habibzadeh, P., Vintzileos, A., Shokouhi, S., Miralles-Wilhelm, F. and Amoroso, A. (2020). Temperature and latitude analysis to predict potential spread and seasonality for COVID-19. Social Science Research Network, Rochester, NY. https://doi.org/10.213 9/ssrn.3550308

Sharma, S., Zhang, M., Anshika, Gao, J., Zhang, H. and Kota, S.H. (2020). Effect of restricted emissions during COVID-19 on air quality in India. Sci. Total Environ. 728: 138878. https://doi.org/10.1016/j.scitotenv.2020.13 8878

Shi, P., Dong, Y., Yan, H., Li, X., Zhao, C., Liu, W., He, M., Tang, S. and Xi, S. (2020). The impact of temperature and absolute humidity on the coronavirus disease 2019 (COVID-19) outbreak - evidence from China. medRxiv 2020.03.22.20038919. https://doi.org/10.1101/2020.03.2 2.20038919

Singh, S. and Naseema, B. (2013). Direct radiative effects of an unseasonal dust storm at a western Indo Gangetic Plain station Delhi in ultraviolet, shortwave, and longwave regions. Geophys. Res. Lett. 40: 2444-2449. https://doi.org/10.1002/grl.50496

Sopian, A., Jalaludin, J., Mayusi, T.Z.A.T. and Latif, M.T. (2020). Increased chromosomal damage among children in proximity to industrial zone. Aerosol Air Qual. Res. 20: 944-955. https://doi.org/10.4209/aaqr.2019.12.0653

Suhaimi, N.F., Jalaludin, J. and Latif, M.T. (2020). Demystifying a possible relationship between COVID19, air quality and meteorological factors: Evidence from Kuala Lumpur, Malaysia. Aerosol Air Qual. Res. 20: 1520-1529. https://doi.org/10.4209/aaqr.2020.05.0218

Tiwari, S., Bisht, D.S., Srivastava, A.K., Pipal, A.S., Taneja, A., Srivastava, M.K. and Attri, S.D. (2014). Variability in atmospheric particulates and meteorological effects on their mass concentrations over Delhi, India. Atmos. Res. 145-146: 45-56. https://doi.org/10.1016/j.atmosres.2014. 03.027

Tosepu, R., Gunawan, J., Effendy, D.S., Ahmad, L.O.A.I., Lestari, H., Bahar, H. and Asfian, P. (2020). Correlation between Weather and Covid-19 Pandemic in Jakarta, Indonesia. Sci. Total Environ. 725: 138436. https://doi.org/ 10.1016/j.scitotenv.2020.138436

United Nations (2018). 2018 revision of world urbanization prospects. https://www.un.org/development/desa/publica tions/2018-revision-of-world-urbanization-prospects.html

Van Doremalen, N., Bushmaker, T. and Munster, V.J. (2013). Stability of Middle East respiratory syndrome coronavirus (MERS-CoV) under different environmental conditions. Eurosurveillance 18: 20590. https://doi.org/1 0.2807/1560-7917.es2013.18.38.20590

Wang, J., Tang, K., Feng, K. and Lv, W. (2020). High temperature and high humidity reduce the transmission of COVID-19. SSRN 3551767. https://doi.org/10.2139/ssrn. 3551767

World Health Organization (WHO) (2016). WHO Global 
Urban Ambient Air Pollution Database (Update 2016). https://www.who.int/phe/health_topics/outdoorair/databa ses/cities/en/

World Health Organization (WHO) (2020a). Coronavirus disease 2019 (COVID-19): Situation report, 51. World Health Organization. https://apps.who.int/iris/handle/106 $65 / 331475$

World Health Organization (WHO) (2020b). Modes of transmission of virus causing COVID-19: Implications for IPC precaution recommendations. Scientific brief. https://www.who.int/news-room/commentaries/detail/m odes-of-transmission-of-virus-causing-covid-19-implicat ions-for-ipc-precaution-recommendations

World Population Review (2020). World city populations 2020. https://worldpopulationreview.com/world-cities/

Yin, Y. and Wunderink, R.G. (2018). MERS, SARS and other coronaviruses as causes of pneumonia. Respirology
23: 130-137. https://doi.org/10.1111/resp.13196

Zhu, Y., Xie, J., Huang, F. and Cao, L. (2020). Association between short-term exposure to air pollution and COVID19 infection: Evidence from China. Sci. Total Environ. 727: 138704. https://doi.org/10.1016/j.scitotenv.2020.13 8704

Zoran, M.A., Savastru, R.S., Savastru, D.M. and Tautan, M.N. (2020). Assessing the relationship between ground levels of ozone $\left(\mathrm{O}_{3}\right)$ and nitrogen dioxide $\left(\mathrm{NO}_{2}\right)$ with coronavirus (COVID-19) in Milan, Italy. Sci. Total Environ. 740: 140005. https://doi.org/10.1016/j.scitotenv. 2020.140005

Received for review, June 14, 2020 Revised, August 5, 2020 Accepted, August 7, 2020 